\title{
丹治義之 学位論文審査要旨
}

\begin{tabular}{cccc} 
主査 & 池 & 正 & 英 \\
副主査 & 井 & 藤 & 雄 \\
同 & 領 & 家 & 和 \\
\hline
\end{tabular}

\section{主論文}

Runt-related transcription factor 3 expression in human oral squamous cell carcinomas; implication for tumor progression and prognosis

（ヒト口腔扁平上皮癌におけるRUNX3の発現；腫瘍の進行および予後との関連）

（著者：丹治義之、尾崎充彦、長濱由美、小谷 勇、領家和男、井藤久雄）

平成18年 Oral Oncology 掲載予定 


\section{学 位 論 文 要 旨}

\section{Runt-related transcription factor 3 expression in human oral squamous cell carcinomas; implication for tumor progression and prognosis （ヒトロ腔扁平上皮癌におけるRUNX3の発現；腫瘍の進行および予後との関連）}

口腔領域の悪性腫瘍の中で扁平上皮癌（Squamous cell carcinoma：SCC）は最も頻度が 高い。また、口腔上皮の異形成は時にSCCへと発展する前癌病変である。異形成からSCC へ と進展する病理学的機構を検討することは有益である。

Runx とはRuntドメインを有する脊椎動物の遺伝子で、Runx1は造血細胞の分化に、Runx2 は骨形成に、Runx3は胃上皮細胞の増殖制御や春髄神経節の形成に重要な役割を果たすこ とが報告されている。RUNX3はTGF- $\beta$ シグナル経路においてSmad と結合して核内に移行し 転写因子として働き、細胞増殖および細胞分化を制御していると報告されている。また、 ヒト胃癌ではRUNX3 mRNA発現がメチル化により抑制され、胃癌の形成や進展に関与寸るこ とが報告されている。近年、胃癌、肺癌、食道癌、大腸癌、肝細胞癌など様々な七卜悪性 腫瘍においてRUNX3蛋白の発現減少が報告されている。しかしながら、口腔癌におけるRUNX3 発現に関する報告はない。

そこで、ヒトの口腔正常粘膜、異形成、SCCにおけるRUNX3蛋白の発現を免疫組織化学的 に検討し、Ki-67、P21、P27、アポトーシスと比較するとともに、臨床病理学的因子との関 連について解析した。

\section{方 法}

ヒト口腔扁平上皮癌細胞株 (HSC3, HSC4, SCCKN) を培養し、ウエスタンブロット法でRUNX3 蛋白の発現を調べた。また、手術材料非腫瘍部と腫瘍部におけるRUNX3蛋白の発現を調べ た。正常口腔粘膜10部位、異形成51病変、SCC108病変のホルマリン固定、パラフィン包埋 標本を用いて免疫組織化学的検討を行なった。病理診断はHE染色プレパラートを用い、WHO の診断基準によってSCCを高分化、中分化、低分化の 3 種類に分類した。免疫組織化学はス トレプトアビジンービオチンーペルオキシダーゼ法にて行い、抗RUNX3ポリクローナル抗体、 抗Ki-67モノクローナル抗体、抗P21モノクローナル抗体、抗P27モノクローナル抗体を用い た。それぞれ1000個以上の細胞を数え、陽性細胞数をパーセンテージで表し、ラベリング インデックス (Labeling index:LI) とした。アポトーシスについてはTUNEL法を用い、TUNEL 陽性細胞比率：アポトーシスインデックス（Apoptosis index：AI）として表した。RUNX3LI が5\%未満を低発現、5\%以上を高発現とし、RUNX3蛋白発現と他のマーカーとを比較検討し 
た。また、SCC症例のうち、StageII-IVの85症例について、RUNX3低発現群と高発現群にお ける生存率をKaplan-Meier法を用いて検討した。

\section{結 果}

ウエスタンブロット法で、扁平上皮癌細胞株 (HSC3、HSC4、SCCKN) においてRUNX3蛋白の 発現は見られなかったが、手術材料においては非腫瘍部、腫瘍部でともにRUNX3蛋白の発現 が見られた。一方、免疫組織化学でRUNX3蛋白は正常粘膜、異形成では有棘層から表層細胞 に、また、SCCでは癌真珠周囲の腫瘍細胞に発現し、いずれも主に細胞質に分布していた。

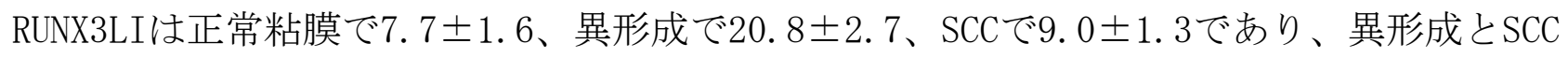

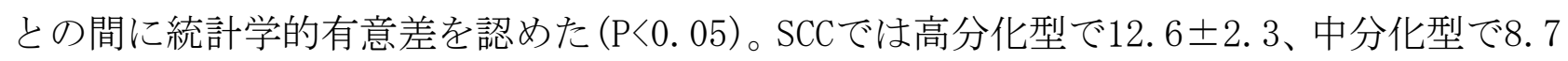
\pm 2.2 、低分化型で $2.3 \pm 1.0$ あり、SCCの分化度とRUNX3蛋白の発現との間には有意な相関 性が認められた $(\mathrm{P}<0.01)$ 。その他の検討した臨床病理学的因子とRUNX3蛋白の発現との関 連はなかった。また、SCCにおけるRUNX3蛋白の発現とKi-67との間に逆相関がみられた

（P<0.01）が、P21、P27、AIとの間には関連は見られなかった。SCC 85症例（StageII-IV） におけるRUNX3低発現群は高発現群と比較して有意に予後不良であった（P<0.05）。

\section{考 察}

本研究ではヒト口腔正常粘膜、異形成、SCCにおけるRUNX3蛋白の発現を明らかにした。 ウエスタンブロット法では手術材料において腫瘍部、非腫瘍部共にRUNX3蛋白の発現を認め た。細胞株でのRUNX3蛋白発現欠落は過去の他臓器における報告のように、RUNX3遺伝子の メチル化による可能性が推測された。免疫組織化学ではRUNX3蛋白は正常粘膜および異形成 において、有棘層から表層の分化した細胞に発現していた。SCCにおいては癌真珠周囲に発 現し、組織学的分化度とRUNX3蛋白発現との相関性を裏付ける結果であった。RUNX3LIはSCC の分化度と関連し、Ki-67とは逆相関を示し、RUNX3は有棘層から表層の細胞質に発現し、 増殖能の高い基底細胞層では発現しないことからRUNX3は細胞分化ならびに増殖の制御に 関連することが示唆された。一方、RUNX3LIはP21、P27、AI と統計学的な関連はなく、ヒト 口腔癌においてRUNX3はこれらCDKインヒビターの発現およびアポトーシス誘導と関連しな いことが示唆された。一般に低分化型SCCは高、中分化型SCCよりも予後不良といわれてい るが、本研究において分化度とRUNX3発現の相関およびRUNX3発現と予後との有意な関連が 示されたことにより、RUNX3が分化度と予後の関連を結びつける重要な因子であると考えら れた。

最近の研究ではTGF- $\beta$ 経路におけるSmadが腫瘍抑制因子として働くことが報告されており、 TGF- $\beta$ によって活性化され、RUNX3による相互作用によって修飾されるSmadはさまざまなヒ 卜悪性腫瘍において患者の予後独立因子として報告されている。RUNX3はヒト口腔扁平上皮 
癌において子後因子の一つであることが示唆された。

\section{結 論}

口腔正常粘膜や口腔扁平上皮癌におけるRUNX3蛋白の発現は細胞の分化および増殖抑制 に関与すると考えられた。また、RUNX3は口腔扁平上皮癌の予後因子となることが示唆され た。 